
ISSN : 2615-1995, E-ISSN : 2615-0654

J. Madani., Vol. 3, No. 2, September 2020 (319 - 327)

C2018 Lembaga Kajian Demokrasi

dan Pemberdayaan Masyarakat (LKD-PM)

DOI : https://doi.org/10.33753/madani.v3i2.136

\title{
Pengaruh Kesiapan Belajar dan Pengulangan Latihan Terhadap Hasil Belajar Ekonomi Dengan Reinforcement Sebagai Variabel Intervening Pada PKBM Cipta Tunas Karya
}

\author{
Citra Eliyani \\ Fakultas Ekonomi, Universitas Pamulang \\ citradarmaji@gmail.com \\ Ivan Putranto \\ Fakultas Ekonomi, Universitas Pamulang \\ ivanputranto21@gmail.com
}

\begin{abstract}
Abstrak
Penelitian ini bertujuan untuk mengetahui pengaruh kesiapan belajar terhadap hasil belajar siswa PKBM Cipta Tunas Karya, untuk mengetahui pengaruh kesiapan belajar terhadap hasil belajar siswa PKBM Cipta Tunas Karya dengan pemberian reinforcement sebagai variabel intervening, untuk mengetahui pengaruh pengulangan latihan terhadap hasil belajar siswa PKBM Cipta Tunas Karya, dan untuk mengetahui pengaruh pengulangan latihan terhadap hasil belajar siswa PKBM Cipta Tunas Karya dengan pemberian reinforcement sebagai variabel intervening. Populasi dalam penelitian ini adalah seluruh siswa kelas X, XI, XII pada PKBM Cipta Tunas Karya, dengan sampel sebanyak 100 siswa. Teknik analisis data yang digunakan adalah analisis jalur. Hasil penelitian ini adalah 1) kesiapan belajar berpengaruh terhadap hasil belajar siswa pada PKBM Cipta Tunas Karya. Hasil perhitungan AMOS menunjukkan koefisien jalur yang bertanda positif sebesar 0,425 dengan nilai C.R sebesar 3,633 ( $\geq 1,96)$ pada taraf signifikansi 5\% dan diperoleh probabilitas signifikansi $(p)$ sebesar 0,000. Nilai ini lebih kecil dari taraf signifikansi ( $p$ ) yang ditentukan yaitu 0,05. 2) kesiapan belajar berpengaruh terhadap hasil belajar melalui reinforcement pada PKBM Cipta Tunas Karya. Hasil perhitungan AMOS dan perhitungan score Zsobel diperoleh nilai 3,03722729 ( $\geq 1,96) 3)$ pengulangan latihan berpengaruh terhadap hasil belajar pada PKBM Cipta Tunas Karya. Hasil perhitungan AMOS menunjukkan koefisien jalur yang bertanda positif sebesar 0,295 dengan nilai C.R sebesar 2,578 ( $\geq 1,96)$ 4) pengulangan latihan berpengaruh terhadap hasil belajar melalui reinforcement pada PKBM Cipta Tunas Karya. Hasil perhitungan AMOS dan perhitungan score Zsobel diperoleh nilai 2,86677625 ( $\geq 1,96)$.
\end{abstract}

Kata Kunci : Kesiapan Belajar, Pengulangan Latihan, Reinforcement, Hasil Belajar

\begin{abstract}
This study aims to determine the effect of learning readiness on the learning outcomes of PKBM Cipta Tunas Karya students, to determine the effect of learning readiness on learning outcomes of PKBM Cipta Tunas Karya students by providing reinforcement, to determine the effect of repetition of exercises on learning outcomes of PKBM Cipta Tunas Karya students, and to determine the effect of repetition of exercises on the learning outcomes of PKBM Cipta Tunas Karya students by providing reinforcement. The population in this study were all students of class X, XI, XII at PKBM Cipta Tunas Karya, with a sample of 100 students. The data analysis technique used is path analysis. The results of this study are 1) learning readiness affects student learning outcomes at PKBM Cipta Tunas Karya. The results of the AMOS calculation show a positive path coefficient of 0.425 with a C.R value of $3.633(\geq 1.96)$ at the $5 \%$ significance level and a significance probability $(p)$ of 0.000 is obtained. This value is smaller than the specified significance level (p), around 0.05.2) readiness to learn affects
\end{abstract}


learning outcomes through reinforcement on PKBM Cipta Tunas Karya. The results of the AMOS calculation and the Zsobel score calculation obtained a value of $3.03722729(\geq 1.96) 3)$ repetition of the exercises had an effect on learning outcomes at PKBM Cipta Tunas Karya. The results of AMOS calculations show a positive path coefficient of 0.295 with a C.R value of $2.578(\geq 1.96)$ 4) repetition of exercises has an effect on learning outcomes through reinforcement on PKBM Cipta Tunas Karya. The results of AMOS calculations and the calculation of the Zsobel score obtained a value of $2.86677625(\geq 1.96)$.

Keywords : Learning Readiness, Exercise Repetition, Reinforcement, Learning Outcomes

\section{PENDAHULUAN}

Pendidikan merupakan upaya yang dilakukan dalam rangka membantu perkembangan potensi diri siswa sebagai makhluk individu maupun makhluk sosial. Melalui pendidikan siswa dibekali ilmu pengetahuan dan keterampilan. Dalam Undang-Undang Nomor 20 Tahun 2003 tentang Sistem Pendidikan Nasional disebutkan bahwa pendidikan adalah usaha sadar dan terencana untuk mewujudkan suasana belajar dan proses pembelajaran agar peserta didik secara aktif mengembangkan potensi dirinya untuk memiliki kekuatan spritual keagamaan, pengendalian diri, kepribadian, kecerdasan, akhlak mulia, serta keterampilan yang diperlukan dirinya, masyarakat, bangsa, dan negara.

Pendidikan merupakan salah satu proses dalam pembelajaran yang dilakukan untuk mencapai tujuan pembelajaran. Tujuan pembelajaran adalah meningkatkan mutu pendidikan agar menghasilkan para peserta didik yang mempunyai kualitas dan kemampuan untuk dapat bersaing di era globalisasi. Salah satu indikator yang yang digunakan melihat keberhasilan dari tujuan pendidikan adalah hasil belajar siswa, yang dapat dilihat dari penguasaan materi belajar siswa melalui evaluasi pembelajaran serta kemampuan siswa memecahkan masalah.

Hasil belajar yang dicapai seseorang merupakan hasil interaksi antara berbagai faktor yang mempengaruhi baik dari dalam diri (faktor internal) maupun dari luar diri (faktor eksternal) siswa. Hasil belajar yang baik menunjukkan keberhasilan dalam proses kegiatan belajar mengajar, sebaliknya hasil belajar yang tidak baik menunjukkan bahwa kegiatan belajar mengajar belum optimal sehingga tujuan pembelajaran belum tercapai.
Berdasarkan hasil observasi yang dilakukan, diketahui bahwa hasil belajar pada Pusat Kegiatan Belajar Masyarakat (PKBM) Cipta Tunas Karya masih belum optimal. Hal ini dapat dilihat masih rendahnya hasil belajar yang didapatkan oleh siswa.

Menurut Djamarah dan Zain (2016: 121) untuk mengukur tingkat ketuntasan belajar sebagai berikut.

1. Istimewa/maksimal apabila seluruh bahan pelajaran yang diajarkan dapat dikuasai oleh siswa $100 \%$.

2. Baik sekali/optimal apabila sebagian besar dapat dikuasai siswa yaitu 76\%-99\%.

3. Baik/minimal apabila bahan pelajaran yang dikuasai siswa sebesar 60\%-76\%.

4. Kurang apabila bahan pelajaran yang dikuasai siswa sebesar $<60 \%$.

Belum optimalnya hasil belajar dapat diseabkan oleh faktor internal dan faktor eksternal. Faktor internal berasal dari dalam diri siswa seperti kecerdasan atau intelegensi, bakat, minat, motivasi, kesiapan belajar dan sebagainya. Faktor eksternal berasal dari luar diri siswa seperti metode mengajar guru, kurikulum, ketersediaan sarana belajar, intensititas atau pengulangan materi, penguatan guru dan sebagainya. Dari sekian banyak faktor yang dapat menyebabkan belum optimalnya hasil belajar, faktor kesiapan belajar, intensititas atau pengulangan materi, dan penguatan guru diduga memberikan sumbangsih negatif terhadap hasil belajar.

Salah satu faktor yang dapat mempengaruhi hasil belajar adalah kesiapan belajar. Kesiapan belajar merupakan hal awal sebelum pembelajaran dimulai. Siswa harus mempersiapkan diri sebelum kegiatan belajar. Siswa yang tidak siap belajar akan berpengaruh pada terganggunya proses 
pembelajaran sehingga hasil belajar tidak optimal. Siap belajar artinya, memiliki kondisi fisik yang prima, kondisi mental, emosional yang stabil, siap pengetahuan misalnya membaca buku pelajaran dan membaca berita dari berbagai media, serta siap secara materiil misalnya kelengkapan fasilitas yang mendukung proses pembelajaran seperti buku tulis, buku catatan, alat tulis, dan perlengkapan lainnya. Kesiapan belajar pada siswa PKBM Cipta Tunas Karya masih rendah. Hal ini dapat dilihat pada saat kegiatan belajar mengajar akan dimulai siswa terlihat masih bercanda dengan teman sebelahnya, asik dengan handphone-nya, belum mempersiapkan buku pelajaran dan materi. Hal ini tentu saja akan mengakibatkan proses belajar mengajar tidak akan maksimal.

Selain kesiapan belajar faktor pengulangan latihan juga diduga memberikan pengaruh terhadap hasil belajar siswa. Pengulangan latihan termasuk faktor internal yang mempengaruhi hasil belajar. Siswa yang sering melakukan pengulangan latihan-latihan akan mengingat materi lebih banyak sehingga hasil belajarnya akan semakin baik. Pengulangan akan membuat informasi memasuki memori jangka panjang sehingga informasi tersebut tidak mudah terlupakan. Pengulangan latihan pada siswa PKBM Cipta Tunas Karya masih tergolong rendah. Ketika guru memberikan latihan latihan, siswa kurang antusias, sehingga ketika pembelajaran selesai siswa tidak mengulangi latihan tersebut.

Pada saat pembelajaran berlangsung, pemberian reinforcement atau penguatan juga dapat mempengaruhi hasil belajar siswa. Pemberian reinforcement atau penguatan merupakan pemberian respon terhadap aktivitas siswa yang positif. Umpan balik tersebut dapat berupa pujian dan pengakuan baik secara verbal dan non-verbal sehingga diharapkan penerimanya akan terus mengulang kegiatan positif tersebut. pemberian reinforcement bertujuan meningkatkan perhatian siswa selama pembelajaran berlangsung, meningkatkan motivasi belajar, meningkatkan kegiatan belajar dan membina tingkah laku siswa yang produktif. Berdasarkan hasil observasi pada PKBM Cipta Tunas Karya diketahui bahwa pada dasarnya guru sudah memberikan reinforcement atau pe- nguatan pemberian respon terhadap aktivitas siswa yang positif misalnya seperti tepuk tangan ketika siswa berhasil menjawab atau mengerjakan soal yang diberikan, tetapi intensitasnya masih sangat kurang. Padahal pemberian reinforcement akan meningkatkan motivasi siswa atau rasa percaya diri pada siswa tersebut.

\section{METODE}

\section{Desain Penelitian}

Penelitian ini merupakan penelitian kuantitatif yang tergolong ke dalam suatu penelitan kausal. Menurut Sugiyono (2010: 19), peneliti kuantitatif dalam melihat hubungan variabel lebih bersifat sebab dan akibat (kausal), sehingga dalam penelitiannya ada variabel independen dan dependen. Dari variabel tersebut selanjutnya dicari seberapa besar pengaruh variabel independen terhadap dependen.

\section{Populasi dan Sampel}

Populasi dalam penelitian ini adalah seluruh siswa kelas X, XI, XII pada Pusat Kegiatan Belajar Masyarakat (PKBM) Cipta Tunas Karya. Berpedoman pada Hair et al (2010:101) yang menyatakan bahwa angka chi- square rentan terhadap jumlah sampel, maka sampel yang disarankan adalah berkisar antara 100-200, sehingga untuk mendapatkan hasil optimal, penelitian ini menggunakan sampel sebanyak 100 siswa.

\section{Teknik Analisis Data}

1. Analisis Deskriptif

2. Uji Asumsi Klasik
a. Uji Normalitas
b. Uji Multikolinieritas
c. Uji Heteroskedastisitas

3. Uji Hipotesis

Analisis Jalur

\section{HASIL dan PEMBAHASAN \\ Kesiapan Belajar}

Menurut Slameto (2003: 113) kesiapan adalah keseluruhan kondisi seseorang yang membuatnya siap untuk memberi respon/jawaban di dalam 
cara tertentu terhadap suatu situasi. Adapun menurut Nasution (2010: 179) pengertian kesiapan belajar adalah kondisi-kondisi yang mendahului kegiatan belajar itu sendiri. Kondisi yang mendahului belajar itu terdiri atas perhatian, motivasi, dan perkembangan kesiapan.

\section{Pengulangan Latihan}

Latihan merupakan kegiatan yang selalu dilakukan dalam proses pembelajaran. Tujuannya adalah sebagai salah satu evaluasi atau penentu hasil belajar siswa. Siswa yang mendapat nilai baik setiap mengerjakan latihan dapat dikatakan bahwa siswa tersebut mampu melewati proses pembelajaran dengan sangat baik. Semakin sering pengulangan latihan dilakukan maka akan semakin ahli dalam mengerjakan apa saja yang mendukung proses belajar. Menurut Djamarah (2008: 42) pengulangan sangat membantu untuk memperbaiki semua kesan yang masih samar-samar untuk menjadi kesan-kesan yang sesungguhnya, yang tergambar jelas dalam ingatan. Adapun menurut Darsono (2000: 28) latihan berarti siswa mengulangulang materi yang dipelajari sehingga materi tersebut makin mudah diingat.

Menurut Anni (2009: 91) model berikut merupakan upaya menunjukkan cara kerja memori dan membantu menjelaskan tindakan yang harus dilakukan oleh pembelajar dalam memperkuat memori.

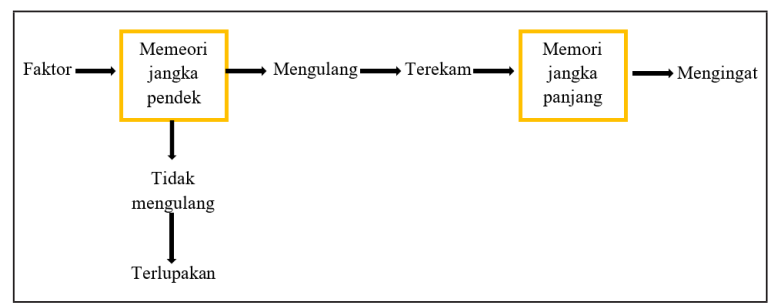

Gambar 1. Model Pengulangan Belajar

\section{Hasil Belajar}

Sudjana (2014: 24) mengemukakan hasil belajar adalah kemampuan-kemampuan yang dimiliki siswa setelah dia menerima pengalaman belajarnya. Adapun Dimyati dan Mudjiono (2013: 3) menerangkan bahwa hasil belajar merupakan hasil dari suatu interaksi tindakan belajar dan tindakan mengajar. Dari sisi guru, tindak mengajar diakhiri dengan proses evaluasi hasil belajar. Dari sisi peserta didik, hasil belajar merupakan puncak proses belajar. Pendapat lain menurut Nana Sudjana (2014: 3) mendefinisikan hasil belajar siswa pada hakikatnya adalah perubahan tingkah laku sebagai hasil belajar dalam pengertian yang lebih luas mencakup bidang kognitif, afektif, dan psikomotorik.

\section{Reinforcement}

Pemberian reinforcement merupakan Pemberian umpan balik berupa pujian atau pengakuan ketika seseorang sudah berusaha melakukan halhal positif. Hal ini bertujuan baik bagi orang tersebut, karena akan semakin giat lagi melakukan hal baik karena merasa hasil kerja kerasnya dihargai. Usman (2013: 80) mengemukakan penguatan adalah segala bentuk respon, bersifat verbal maupun nonverbal yang merupakan bagian tingkah laku guru terhadap tingkah laku siswa yang dianggap positif, dan mempunyai tujuan memberikan umpan balik bagi penerima atas perbuatannya sebagai suatu dorongan. Hal ini didukung oleh pendapat Anitah (2014: 7.25) penguatan berarti respon yang diberikan oleh guru kepada siswa terhadap perilaku yang dianggap baik, dan dapat membuat terulangnya atau meningkatnya perilaku baik tersebut.

Menurut Hasibuan (2012: 58) "penguatan adalah tingkah laku dalam merespon secara positif suatu tingkah laku tertentu siswa yang memungkinkan tingkah laku tersebut timbul kembali". Itu artinya, Pemberian reinforcement di sekolah berupa respon positif yang diberikan guru terhadap hasil belajar siswa akan memberikan dorongan bagi siswa yang menerimanya, sehingga mereka akan mengulangi kegiatan positifnya

\section{Hasil}

\section{Deskripsi Data Penelitian}

\begin{tabular}{|l|l|r|r|r|r|r|}
\hline \multicolumn{7}{|c|}{ Tabel 1. Deskripsi Data Penelitian } \\
\hline & & \multicolumn{1}{c|}{$X_{1}$} & \multicolumn{1}{c|}{$X_{2}$} & \multicolumn{1}{c|}{$X_{3}$} & \multicolumn{1}{c|}{ Y } & $\begin{array}{c}\text { Valid N } \\
\text { (listwise) }\end{array}$ \\
\hline N & Statistic & 100 & 100 & 100 & 100 & 100 \\
\hline Range & Statistic & 15 & 14 & 16 & 19 & \\
\hline Minimum & Statistic & 19 & 19 & 17 & 25 & \\
\hline Maximum & Statistic & 34 & 33 & 33 & 44 & \\
\hline
\end{tabular}




\begin{tabular}{|l|l|r|r|r|r|l|}
\hline Sum & Statistic & 2726 & 2723 & 2711 & 3682 & \\
\hline \multirow{3}{*}{ Mean } & Statistic & 27.26 & 27.23 & 27.11 & 36.82 & \\
\cline { 2 - 7 } & Std. Error & .301 & .300 & .275 & .389 & \\
\hline Std. Deviation & Statistic & 3.014 & 3.001 & 2.748 & 3.888 & \\
\hline Variance & Statistic & 9.083 & 9.007 & 7.553 & 15.119 & \\
\hline \multicolumn{70}{|c|}{ Sumber: Data diolah 2020 } \\
\hline
\end{tabular}

Berdasarkan tabel di atas menunjukkan bahwa $\mathrm{N}$ atau jumlah data setiap variabel yang valid berjumlah 100, dari 100 data sampel kesiapan belajar, pengulangan latihan, reinforcement, dan hasil belajar. Setiap variabel memiliki nilai mean lebih besar dari nilai standar deviasi sehingga penyimpangan data yang terjadi rendah maka penyebaran nilainya merata.

Kesiapan belajar memiliki nilai minimum 19 dan nilai maksimum 34, rata- rata nilainya 27, 26. Nilai rata-rata kesiapan belajar siswa tersebut jika dicocokkan dengan kategori skala likert 1-5 maka berada pada kelas ketiga. Artinya kesiapan belajar siswa masih dalam kategori sedang.

Pengulangan latihan memiliki nilai minimum 19 dan nilai maksimum 33, rata-rata nilainya 27, 23. Nilai rata-rata pengulangan latihan siswa tersebut jika dicocokkan dengan kategori skala likert 1-5 maka berada pada kelas ketiga. Artinya kesiapan belajar siswa masih dalam kategori sedang.

Pemberian reinforcement memiliki nilai minimum 17 dan nilai maksimum 33, rata-rata nilainya 27,11 . Nilai rata-rata Pemberian reinforcement siswa tersebut jika dicocokkan dengan kategori skala likert 1-5 maka berada pada kelas ketiga. Artinya Pemberian reinforcement siswa juga masih dalam kategori sedang.

Hasil belajar memiliki nilai minimum 25 dan nilai maksimum 44, rata-rata nilainya 36,82 . Nilai rata-rata hasil belajar siswa tersebut jika dicocokkan dengan kategori skala likert 1- 5 maka berada pada kelas ketiga. Artinya hasil belajar siswa masih dalam kategori sedang.

\section{Uji Asumsi Klasik}

a. Uji Normalitas

\begin{tabular}{|l|l|r|}
\hline \multicolumn{3}{c|}{ Tabel 2. Hasil Uji Normalitas } \\
\hline \multicolumn{3}{c|}{ One-Sample Kolmogorov-Smirnov Test } \\
\hline N & & $\begin{array}{c}\text { Unstandardized } \\
\text { Residual }\end{array}$ \\
\hline
\end{tabular}

\begin{tabular}{|l|l|r|}
\hline \multirow{2}{*}{ Normal Parameters ${ }^{a, b}$} & Mean & .0000000 \\
\cline { 2 - 3 } & Std. Deviation & 2.71221719 \\
\hline \multirow{2}{*}{ Most Extreme Differences } & Absolute & .066 \\
\cline { 2 - 3 } & Positive & .042 \\
\cline { 2 - 3 } & Negative & -.066 \\
\hline Test Statistic & .066 \\
\hline Asymp. Sig. (2-tailed) & .200 \\
\hline a. Test distribution is Normal & \multicolumn{2}{|c|}{ Sumber: Data diolah 2020 } \\
\hline \multicolumn{2}{|c|}{} \\
\hline
\end{tabular}

Berdasarkan tabel di atas tampak bahwa nilai signifikansi (Asymp. Sig. (2-tailed)) sebesar 0,2 lebih besar dari 0,05, sehingga dapat disimpulkan bahwa data yang diuji dalam penelitian ini berdistribusi normal. Untuk lebih membuktikan uji normalitas data dengan software SPSS terhadap 100 siswa kelas X, XI, dan XII siswa PKBM CIpta Tunas Karya, tampak pada grafik dibawah ini:

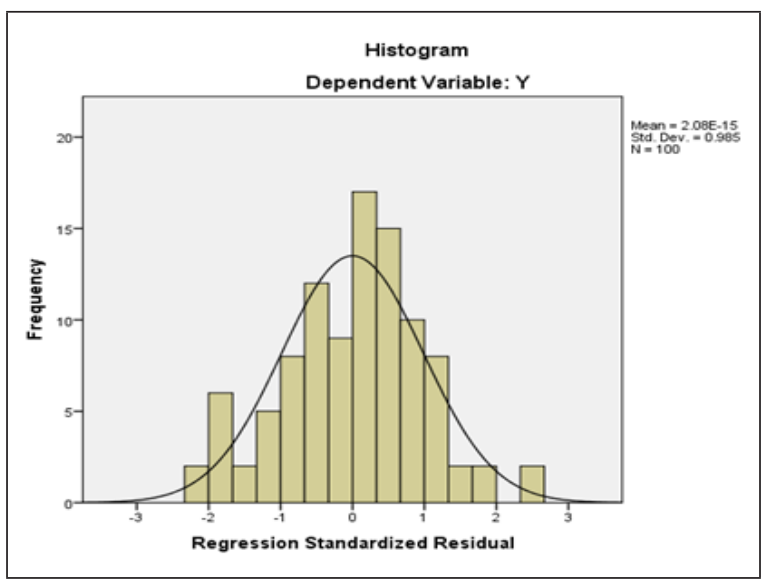

Gambar 2. Grafik Histogram Uji Normalitas Data

\section{b. Uji Multikolinearitas}

\begin{tabular}{|l|c|c|}
\hline \multirow{2}{*}{\multicolumn{1}{c|}{ Variabel }} & Collinearity Statistics \\
\cline { 2 - 3 } & Tolerance & VIF \\
\hline (Constant) & & 1.015 \\
\hline Kesiapan belajar & 0.985 & 1.015 \\
\hline Pengulangan latihan & 0.985 & 1.000 \\
\hline reinforcement & 1.000 & Sumber: Data diolah 2020 \\
\hline a. Dependent Variable: hasil belajar \\
\hline \multicolumn{3}{|c|}{} \\
\hline
\end{tabular}

Berdasarkan tabel di atas, tampak nilai tolerance variabel bebas lebih besar dari 0,1, sedangkan nilai VIF berada disekitar angka 1 atau lebih kecil dari angka 10. Hal tersebut dapat disimpulkan bahwa model penelitian ini terbebas dari masalah multikolinearitas 


\section{c. Uji Heteroskedastisitas}

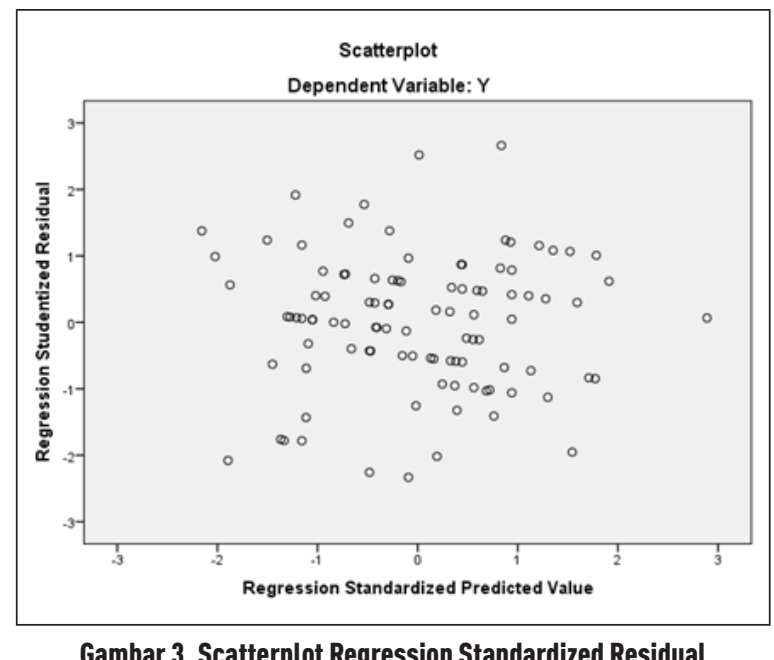

Berdasarkan gambar di atas tampak titik menyebar secara acak, tidak membentuk sebuah pola tertentu yang jelas, tersebar baik dibawah atau diatas angka 0 pada sumbu Y. hal tersebut menunjukkan tidak terjadi masalah heteroskedastisitas pada model sehingga model layak untuk dipakai.

\section{Uji Hipotesis}

Pada proses ini akan dijelaskan hasil uji hipotesis pengaruh kesiapan belajar, pengulangan latihan terhadap hasilbelajar melalui reinforcement pada Pusat Kegiatan Belajar Masyarakat (PKBM) Cipta Tunas Karya. Uji hipotesis path analysis pada penelitian ini menggunakan bantuan program AMOS versi 22.0. kriteria pengujian hipotesis pada penelitian ini adalah dengan melihat kolom koefisien jalur (estimates), kolom critical ratio (C.R) dan kolom probabilitas signifikansi (P). Menurut Ferdinand (2002: 59) hubungan variabel dikatakan berpengaruh apabila nilai $\mathrm{CR} \geq 1,96$ pada taraf signifikansi 5\%. Menurut Ghozali (2014:86) hubungan antar variabel dikatakan berpengaruh positif signifikan apabila koefeisien jalur bernilai positif dan signifikansi $\leq 0,05$. Hasil path analysis pada penelitian ini dapat dilihat pada tabel:

\begin{tabular}{|l|c|c|c|c|c|}
\hline \multicolumn{1}{|c|}{ Tabel 4. Hasil Uji Hipotesis } \\
\hline & Estimate & S.E. & C.R. & P & Label \\
\hline $\begin{array}{l}\text { reinforcement <--- kesiapan } \\
\text { belajar }\end{array}$ & .405 & .082 & 4.939 & $* * *$ & \\
\hline $\begin{array}{l}\text { reinforcement <--- pengulangan } \\
\text { latihan }\end{array}$ & .352 & .082 & 4.272 & $* * *$ & \\
\hline
\end{tabular}

\begin{tabular}{|l|c|c|c|c|c|}
\hline hasil belajar <--- reinforcement & .493 & .128 & 3.843 & $* * *$ & \\
\hline $\begin{array}{l}\text { hasil belajar <--- kesiapan } \\
\text { belajar }\end{array}$ & .425 & .117 & 3.633 & $* * *$ & \\
\hline $\begin{array}{l}\text { hasilbelajar <--- pengulangan } \\
\text { latihan }\end{array}$ & .295 & .114 & 2.578 & .010 & \multicolumn{5}{|c|}{ Sumber: Data diolah 2020 } \\
\hline \multicolumn{4}{|c|}{} \\
\hline
\end{tabular}

Tabel 5. Penjelasan Hasil Uji Path Analysis (Pengaruh Langsung)

\begin{tabular}{|c|c|c|c|c|}
\hline $\begin{array}{l}\text { Pengaruh } \\
\text { langsung }\end{array}$ & $\begin{array}{c}\text { Koefisien } \\
\text { Jalur }\end{array}$ & $\begin{array}{c}\text { Standar } \\
\text { Error }\end{array}$ & P-Value & $\begin{array}{l}\text { R-Square (koefos- } \\
\text { oen determinasi) }\end{array}$ \\
\hline $\begin{array}{l}\text { Kesiapan } \\
\text { belajar terhadap } \\
\text { reinforcement }\end{array}$ & 0,405 & 0,082 & $\begin{array}{l}{ }^{* * *} \text { artinya nilai } \\
\text { P-Value }<0,001 \text {, } \\
\text { kesiapan belajar } \\
\text { berpengaruh } \\
\text { positif dan } \\
\text { signifikan terhadap } \\
\text { reinforcement }\end{array}$ & \multirow{2}{*}{$\begin{array}{l}\text { 0, } 580 \text { (kesiapan be- } \\
\text { lajar dan pengulan- } \\
\text { gan latihan mampu } \\
\text { menjelaskan variasi } \\
\text { variabel reinforce- } \\
\text { ment sebesar } 58 \% \text { ) }\end{array}$} \\
\hline $\begin{array}{l}\text { Pengulangan } \\
\text { latihan terhadap } \\
\text { reinforcement }\end{array}$ & 0,352 & 0,082 & $\begin{array}{l}\text { *** artinya nilai } \\
\text { P-Value }<0,001 \\
\text {, pengulangan } \\
\text { latihan } \\
\text { berpengaruh } \\
\text { positif dan } \\
\text { signifikan terhadap } \\
\text { reinforcement }\end{array}$ & \\
\hline $\begin{array}{l}\text { Reinforcement } \\
\text { terhadap hasil } \\
\text { belajar }\end{array}$ & 0,493 & 0,128 & $\begin{array}{l}{ }^{* * *} \text { artinya nilai } \\
\text { P-Value }<0,001 \\
\text {, reinforcement } \\
\text { berpengaruh positif } \\
\text { dan signifikan } \\
\text { terhadap hasil } \\
\text { belajar }\end{array}$ & \multirow{3}{*}{$\begin{array}{l}0,657 \text { (reinforce- } \\
\text { ment, kesiapan be- } \\
\text { lajar, dan pengulan- } \\
\text { gan latihan mampu } \\
\text { menjelaskan variasi } \\
\text { variabel hasil belajar } \\
\text { sebesar } 65,7 \% \text { ) }\end{array}$} \\
\hline $\begin{array}{l}\text { Kesiapan } \\
\text { belajar terhadap } \\
\text { hasil belajar }\end{array}$ & 0,425 & 0,117 & $\begin{array}{l}{ }^{* * *} \text { artinya nilai } \\
\text { P-Value }<0,001, \\
\text { kesiapan belajar } \\
\text { berpengaruh positif } \\
\text { dan signifikan } \\
\text { terhadap hasil } \\
\text { belajar }\end{array}$ & \\
\hline $\begin{array}{l}\text { Pengulangan } \\
\text { latihan terhadap } \\
\text { hasil belajar }\end{array}$ & 0,295 & 0,114 & $\begin{array}{l}\text { Artinya } \\
\text { pengulangan } \\
\text { latihan } \\
\text { berpengaruh positif } \\
\text { terhadap hasil } \\
\text { belajar }\end{array}$ & \\
\hline \multicolumn{5}{|c|}{ Sumber: Data diolah 2020} \\
\hline
\end{tabular}

Tabel 6. Penjelasan Hasil Uji Path Analysis (Pengaruh Tidak Langsung)

\begin{tabular}{|l|l|l|}
\hline \multicolumn{1}{|c|}{ Pengaruh tidak langsung } & score zsobel & \multicolumn{1}{|c|}{ Keterangan } \\
\hline $\begin{array}{l}\text { kesiapan belajar- } \\
\text { reinforcement->hasil belajar }\end{array}$ & 3.03722729 & $\begin{array}{l}\text { Nilainya >1,96 artinya } \\
\text { kesiapan belajar signifikan } \\
\text { mempengaruhi hasil belajar } \\
\text { melalui reinforcement. }\end{array}$ \\
\hline $\begin{array}{l}\text { pengulangan latihan- } \\
\text { reinforcement->hasil belajar }\end{array}$ & 2.86677625 & $\begin{array}{l}\text { Nilainya >1,96 artinya } \\
\text { pengulangan latihan } \\
\text { signifikan mempengaruhi } \\
\text { hasil belajar melalui } \\
\text { reinforcement. }\end{array}$ \\
\hline \multicolumn{2}{|c|}{} \\
\hline
\end{tabular}

Berdasarkan tabel di atas tampak bahwa variabel kesiapan belajar berpengaruh langsung terhadap hasil belajar dan kesiapan belajar juga berpengaruh secara tidak langsung terhadap hasil belajar siswa melalui reinforcement. Pengulangan latihan juga berpengaruh baik secara langsung dan tidak langsung terhadap hasil belajar. reinforcement berpengaruh langsung terhadap hasil 
belajar.

Pengaruh antar variabel dianggap signifikan apabila pengaruh variabel-variabel tersebut bernilai positif, nilai C.R variabel $\geq 1,96$ pada taraf signifikansi 5\% dan nilai probabilitas signifikansi (p) lebih kecil dari taraf signifikansi yang ditentukan yaitu 0,05 .

Setelah mengetahui masing- masing variabel yang memiliki pengaruh langsung dan tidak langsung maka langkah proses selanjutnya adalah mengetahui hasil koefisien determinasi $(\mathrm{R} \wedge 2)$ yang dihasilkan dari persamaan path diagram pada tabel berikut ini:

Tabel 7. Koefisien determinasi (squared multiple correlatin)

\begin{tabular}{|c|c|}
\hline Variabel & Keterangan \\
\hline reinforcement & 0,580 \\
\hline Hasil belajar & 0,657 \\
\hline & Sumber: Data diolah 2020 \\
\hline
\end{tabular}

Berdasarkan tabel di atas tampak bahwa dalam model penelitian ini variabel yang secara bersama-sama memberikan pengaruhnya terhadap reinforcement adalah sebesar $58 \%$ yang didasarkan pada kontribusi dua variabel yaitu kesiapan belajar dan pengulangan latihan, Sedangkan kontribusi secara bersama-sama terhadap variabel hasil belajar adalah 65,7\% didasarkan pada kontribusi 3 variabel yaitu kesiapan belajar, pengulangan latihan dan reinforcement.

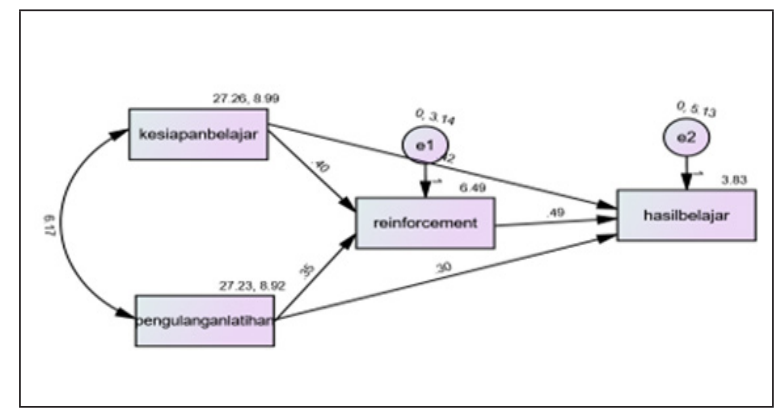

Gambar 4. Final Model Path Analysis

\section{Pembahasan}

1. Pengaruh Kesiapan Belajar Terhadap Hasil Belajar Siswa Pada Pusat Kegiatan Belajar Masyarakat (PKBM) Cipta Tunas Karya

Berdasarkan hasil penelitian menunjukkan ada pengaruh positif dan signifikan kesiapan belajar terhadap hasil belajar. Hal ini berarti bahwa hasil belajar siswa di- tentukan oleh kesiapan sebelum memulai pembelajaran. Siswa yang memiliki kesiapan belajar akan memiliki hasil belajar lebih baik dan sebaliknya. Hal ini didukung oleh penelitian B. Vovi Sinta (2017), kesimpulan hasil penelitiannya bahwa ada pengaruh Kesiapan Belajar Siswa terhadap Hasil Belajar pada Mata Pelajaran Ekonomi Kelas X di SMA Bina Jaya Palembang. Tampak pada persamaan Regresi $=68,11+0,13 \mathrm{X}$ dari pengujian uji " $\mathrm{t}$ " menghasilkan $\mathrm{t}_{\text {hitung }}=2,6>\mathrm{t}_{\text {tabel }}$ $=0,05 / \mathrm{dk} 118=1,671$ maka pada pengujian tersebut $\mathrm{H}_{\mathrm{a}}$ diterima dan $\mathrm{H}_{\mathrm{O}}$ ditolak yang berarti diantara kesiapan belajar ada pengaruh secara signifikan terhadap hasil belajar. Ditambah lagi Agherdien Nuuran (2014) hasil penelitiannya "students who scored high on readiness factors were more likely to succeed in tertiary education". Siswa yang mendapat nilai tinggi dalam faktor- faktor kesiapan lebih mungkin untuk berhasil dalam pendidikan tinggi. Itu artinya kesiapan menjadi penting dalam pembelajaran karena menentukan hasil belajar yang diharapkan.

Sementara, secara tidak langsung kesiapan belajar berpengaruh positif dan signifikan terhadap hasil belajar melalui reinforcement. Hal ini menunjukkan bahwa melalui reinforcement, kesiapan belajar dapat mempengaruhi hasil belajar. Hal ini dikarenakan, siswa tidak hanya memiliki kesiapan belajar yang tinggi melainkan siswa juga memperoleh reinforcement dalam setiap aktivitas yang dilakukan, jika aktivitas positif maka akan mendapat apresiasi atau penguatan yang positif supaya siswa semangat mengulangi kebaikan- kebaikan yang sudah dilakukan dan apabila aktivitas yang dilakukan negatif, siswa mendapatkan hukuman yang sesuai supaya tidak mengulangi perbuatannya lagi. Hal ini mendapat dukungan dari Usman (2013: 81) penguatan mempunyai pengaruh yang baik bagi siswa yang berupa sikap positif terhadap proses belajar.

2. Pengaruh Kesiapan Belajar Siswa Terhadap Hasil Belajar Siswa Pusat Kegiatan Belajar 
Masyarakat (PKBM) Cipta Tunas Karya Dengan Pemberian Reinforcement Sebagai Variabel Intervening

Hasil penelitian ini menyatakan bahwa kesiapan belajar berpengaruh terhadap hasil belajar melalui reinforcement pada Pusat Kegiatan Belajar Masyarakat (PKBM) Cipta Tunas Karya. Hasil perhitungan AMOS dilanjutkan dengan perhitungan score Zsobel diperoleh nilai 3,03722729 $(\geq 1,96)$ Hal ini menunjukkan bahwa variabel kesiapan belajar berpengaruh terhadap hasil belajar melalui reinforcement.

3. Pengaruh Pengulangan Latihan Terhadap Hasil Belajar Siswa Pada Pusat Kegiatan Belajar Masyarakat (PKBM) Cipta Tunas Karya

Hasil penelitian ini menyatakan bahwa pengulangan latihan berpengaruh positif terhadap hasil belajar. Hal ini disebabkan pengulangan latihan akan berdampak baik pada kejelasan siswa, siswa yang gemar melakukan pengulangan latihan akan lebih mudah mengingat pelajaran. Hal ini didukung oleh Penelitian Zuriati (2013) antara pengulangan materi pelajaran ekonomi dirumah $(\mathrm{X})$ dengan Hasil belajar ekonomi siswa (Y) dengan Hasil anlisis Product moment yaitu $\mathrm{r}$ observasi (0.734) lebih besar dari $\mathrm{r}_{\text {tabel }}$ baik pada signifikn 5\% (0.734) dan 1\% (0.296), $\mathrm{H}_{\mathrm{o}}$ ditolak dan $\mathrm{H}_{\mathrm{a}}$ diterima, yang artinya terhadap hubungan yang signifikan antara pengulangan materi pelajaran dirumah terhadap hasil belajar mata pelajaran ekonomi. Barla Novita dkk (2013) hasilnya ada pengaruh tingkat intensitas pemberian latihan soal terhadap prestasi belajar siswa.

Hasil yang sudah diperolah bahwa secara tidak langsung variabel pengulangan latihan berpengaruh positif dan signifikan terhadap hasil belajar melalui reinforcement.

4. Pengaruh Pengulangan Latihan Siswa Terhadap Hasil Belajar Siswa Pada Pusat Kegiatan Belajar Masyarakat (PKBM) Cipta Tunas Karya Dengan Pemberian Reinforcement Sebagai Variabel Intervening

Hasil penelitian ini menyatakan bahwa pengulangan latihan berpengaruh terhadap hasil belajar melalui reinforcement pada $\mathrm{Pu}$ sat Kegiatan Belajar Masyarakat (PKBM) Cipta Tunas Karya. Hasil perhitungan AMOS yang telah disajikan pada tabel dilanjutkan dengan perhitungan score Zsobel diperoleh nilai $2,86677625(\geq 1,96)$. Hal ini menunjukkan bahwa variabel pengulangan latihan berpengaruh terhadap hasil belajar melalui reinforcement.

\section{SIMPULAN}

Kesiapan belajar berpengaruh terhadap hasil belajar Siswa pada Pusat Kegiatan Belajar Masyarakat (PKBM) Cipta Tunas Karya. Hasil perhitungan AMOS menunjukkan koefisien jalur yang bertanda positif sebesar 0,425 dengan nilai C.R sebesar 3,633 $(\geq 1,96)$ pada taraf signifikansi $5 \%$ dan diperoleh probabilitas signifikansi (p) sebesar 0,000. Nilai ini lebih kecil dari taraf signifikansi (p) yang ditentukan yaitu 0,05. Hal ini menunjukkan bahwa variabel kesiapan belajar berpengaruh secara langsung terhadap hasil belajar.

Kesiapan belajar berpengaruh terhadap hasil belajar melalui reinforcement pada Pusat Kegiatan Belajar Masyarakat (PKBM) Cipta Tunas Karya. Hasil perhitungan AMOS dan perhitungan score Zsobel diperoleh nilai 3,03722729 $(\geq 1,96)$ Hal ini menunjukkan bahwa variabel kesiapan belajar berpengaruh terhadap hasil belajar melalui reinforcement.

Pengulangan latihan berpengaruh terhadap hasil belajar pada Pusat Kegiatan Belajar Masyarakat (PKBM) Cipta Tunas Karya. Hasil perhitungan AMOS menunjukkan koefisien jalur yang bertanda positif sebesar 0,295 dengan nilai C.R sebesar 2,578 $(\geq 1,96)$. Hal ini menunjukkan bahwa variabel pengulangan latihan berpengaruh terhadap hasil belajar.

Pengulangan latihan berpengaruh terhadap hasil belajar melalui reinforcement pada Pusat Kegiatan Belajar Masyarakat (PKBM) Cipta Tunas Karya. Hasil perhitungan AMOS dan perhitungan score Zsobel diperoleh nilai 2,86677625 $(\geq 1,96)$. Hal ini menunjukkan bahwa variabel 
pengulangan latihan berpengaruh terhadap hasil belajar melalui reinforcement.

\section{PENGHARGAAN}

Pada kesempatan kali ini penulis ingin mengucapkan terimakasih kepada semua yang terlibat baik secara langsung maupun tidak langsung yang tidak bisa penulis sebutkan satu persatu. Terimakasih atas saran, masukan, dan bantuan, semoga penelitian ini bisa bermanfaat bagi semua pihak.

\section{DAFTAR PUSTAKA}

Anitah, S. (2014). Strategi Pembelajaran di SD. Jakarta: Universitas Terbuka.

Anni, C. T. (2009). Psikologi Belajar. Semarang: UPT UNNES Press.

Arikunto, S. (2010). Prosedur Penelitian Suatu Pendekatan Praktik. Jakarta: Rineka Cipta.

Dalyono. (2015). Psikologi Pendidikan. Jakarta: Rineka Cipta.

Darsono dkk. (2000). Belajar dan Pembelajaran.

Semarang: IKIP Semarang Press.

Dimyati dan Mudjiono. (2013). Belajar dan Pembelajaran. Jakarta:Rineka Cipta.

Djamarah, S. B. (2008). Rahasia Sukses Belajar Edisi Revisi. Jakarta: Rineka Cipta.

Djamarah, S. B dan Zain, A. (2016). Strategi Belajar Mengajar. Jakarta: Rineka Cipta.

Ferdinand, A. (2014). Structural Equation Modelling dalam Penelitian Manajemen. Semarang: Universitas Diponegoro.

Ghozali, I. (2014). Structural Equation Modeling, Metode Alternatif dengan Partial Least Square
(PLS). Edisi 4. Semarang: Badan Penerbit Universitas Diponegoro.

Hair, et al. (2010). Multivariate Data Analyisis Seventh Edition. Pearson Prentice Hall.

Hamalik, O. (2005). Kurikulum dan Pembelajaran. Jakarta: PT Bumi Aksara.

Hasibuan, J.J dan Moedjiono. (2012). Proses Belajar Mengajar. Bandung: PT Remaja Rosdakarya.

Nasution, S. (2010). Berbagai Pendekatan dalam Proses Belajar \& Mengajar. Jakarta: Bumi Aksara.

Riduwan (2008). Pengantar Statistika Untuk Penelitian Pendidikan, Sosial, Ekonomi, Komunikasi, dan Bisnis. Bandung: Alfabeta.

Slameto. (2003). Belajar dan Faktor-Faktor yang Mempengaruhinya. Jakarta: Rineka Cipta.

Sudjana, N. (2014). Penilaian Hasil Proses Belajar Mengajar. Bandung: PT Remaja Rosdakarya. Sugihartono, dkk. (2013). Psikologi Pendidikan. Yogyakarta: UNY Press.

Sugiyono. (2010). Metode Penelitian Kuantitatif Kualitatif \& $R n D$. Bandung: Alfabeta.

Sugiyono (2013). Cara Mudah Menyusun Skripsi, Thesis Dan Disertasi. Bandung: Alfabeta.

Sutarto, J. (2007). Pendidikan Nonformal (Konsep Dasar, Proses Pembelajaran, \& Pemberdayaan Masyarakat). Semarang: Unnes Press.

Uno, H. B. (2012). Orientasi Baru dalam Psikologi Pembelajaran. Jakarta: PT Bumi Aksara. . (2013). Teori Motivasi dan Pengukurannya. 2013. Jakarta: PT Bumi Aksara.

Usman, U. (2013). Menjadi Guru Profesional. Bandung: PT Remaja Rosdakarya. 